\title{
DNA Base Composition and Taxonomy of Some Micrococci
}

\author{
By J. BOHÁC̆EK, M. KOCUR AND T. MARTINEC \\ Institute of Biophysics, Czechoslovak Academy of Sciences, \\ and Czechoslovak Collection of Microorganisms, \\ J. E. Purkyně University, Brno, Czechoslovakia
}

(Accepted for publication 12 October 1966)

\begin{abstract}
SUMMARY
The present report gives the results of studies on the $\%$ guanine + cytosine (GC) content of the DNA of 29 strains designated as Micrococcus, by using the methods of Marmur \& Doty (1962) and Frédéricq, Oth \& Fontaine (1961). In 17 strains agreement was found between their taxonomic position and their $\%$ GC content. Five micrococci formed a very tight cluster around a mean of $50 \%$ GC. It is recommended to classify them in the genus Planococcus Migula. From the DNA base compositions these cocci form a group hitherto not described, intermediate between the genera Staphylococcus and Micrococcus. Micrococcus cryophilus McLean, Sulzbacher \& Mudd, and Micrococcus cerolyticus Friedman \& Kern differ in their \% GC values from those of the genus Micrococcus and should be discarded from the genus. It is confirmed that \% GC content in the DNA in the genus Micrococcus lies within the range of $65-75 \%$.
\end{abstract}

\section{INTRODUCTION}

The usefulness of the study of DNA base compositions for the taxonomy of bacteria has been emphasized by several authors. This approach has given important results in the problem of the classification of aerobic Gram-positive cocci. It was pointed out by Silvestri \& Hill (1965) that aerobic Gram-positive cocci can be divided into two groups on the \% guanine + cytosine (GC) content of their DNAs. The first group, with a low \% GC in DNA, corresponds to the genus Staphylococcus and the second group, with a high \% GC, corresponds to the genus Micrococcus. These conclusions were confirmed by the present authors in a previous paper (Boháček, Kocur \& Martinec, 1965).

Equally significant is the application of this method in solving problems of intrageneric classification. As regards the species within the genus Micrococcus and their DNA base compositions, data on only some of the species can be found in the literature (Belozersky \& Spirin, 1960; Marmur, Falkow \& Mandel, 1963). With the exception of reports by Silvestri \& Hill (1965), Auletta \& Kennedy (1966) and Rosypalová, Boháček \& Rosypal (1966), the \% GC contents of DNA have not directly been used in the classification of the genus Micrococcus. The object of the present paper was to analyse the DNA base composition in species of the genus Micrococcus and to find whether the $\% \mathrm{GC}$ content was in agreement with their classification by other characters. 


\section{METHODS}

In the present study 29 strains of micrococci were investigated; they are listed in Table 1.

Most of the strains were grown on yeast-extract glucose agar (g./1.): yeast-extract, 5; peptone, 5; glucose, 10; agar, 20; $\mathrm{pH} \mathrm{7 \cdot 2.} \mathrm{Micrococcus} \mathrm{halodenitrificans} \mathrm{was} \mathrm{grown}$ on the following medium: (g./1.): beef-extract, 5 ; peptone, $5 ; \mathrm{NaCl}, 80$; agar, 20 ; pH 7-2. M. litoralis was grown on the following medium (g./1.): yeast extract, 5; peptone, 5; glucose, $10 ; \mathrm{KCl}, 2 ; \mathrm{MgSO}_{4} .7 \mathrm{H}_{2} \mathrm{O}, 25 ; \mathrm{NaCl}, 150 ;$ agar, $25 ; \mathrm{pH} \mathrm{7.8}$. The marine micrococci were cultivated in the following medium (g./1.): beef extract, 10; peptone, 10; agar, 20; in sea water, $750 \mathrm{ml}$., tap water, $250 \mathrm{ml}$.

Table 1. List of organisms used

\begin{tabular}{|c|c|c|}
\hline Name & CCM no.* & Other names or numbers \\
\hline Micrococcus luteus & $\left\{\begin{array}{r}132 \\
149 \\
169 \\
337 \\
409 \\
410 \\
840 \\
1674\end{array}\right.$ & $\begin{array}{l}\text { M. lysodeikticus ATCC } 4698 ; \text { NCTC } 2665 \\
\text { Sarcina lutea ATCC } 382 \\
\text { Sarcina lutea ATCC } 272 \\
\text { M. ureae ATCC } 408\end{array}$ \\
\hline Micrococcus roseus & $\left\{\begin{array}{r}679 \\
837 \\
385 \\
560 \\
633 \\
168 \\
1405\end{array}\right.$ & $\begin{array}{l}\text { M. rubens ATCC } 186 \\
\text { ATCC } 416 \\
\text { ATCC } 185 \\
\text { ATCC } 179 \\
\text { ATCC } 412 \\
\text { Staphylococcus roseus }\end{array}$ \\
\hline Micrococcus litoralis & 2226 & Sarcina morrhuae \\
\hline Micrococcus sp. & $\left\{\begin{array}{r}740 \\
825 \\
836 \\
2087\end{array}\right.$ & $\begin{array}{l}\text { M. conglomeratus } \\
\text { M. conglomeratus } \\
\text { ATCC } 401\end{array}$ \\
\hline Micrococcus cerolyticus & 901 & ATCC 12559 \\
\hline Micrococcus denitrificans & $\left\{\begin{array}{r}982 \\
1396\end{array}\right.$ & NCIB 8944; ATCC 13543 \\
\hline Micrococcus halodenitrificans & 286 & ATCC 13511 \\
\hline Micrococcus radiodurans & $\left\{\begin{array}{l}1700 \\
1701\end{array}\right.$ & $\begin{array}{l}\text { ATCC } 13939 \\
\text { UI }\end{array}$ \\
\hline Micrococcus cryophilus & 900 & ATCC 12226 \\
\hline Micrococcus aquivivus & 316 & ATCC 14404 \\
\hline Micrococcus eucinetus & $\left\{\begin{array}{l}2.388 \\
2389\end{array}\right.$ & $\begin{array}{l}\text { XQ58 } \\
\text { XQ40 }\end{array}$ \\
\hline
\end{tabular}

* CCM = Czechoslovak Collection of Microorganisms, University J. E. Purkyně, Brno.

The organisms were incubated at $30^{\circ}$ for $24 \mathrm{hr}$ with the exception of Micrococcus litoralis, which was incubated for 6 days, and $M$. cryophilus which was incubated at $10^{\circ}$ for 2 days.

For the isolation of DNA a method combining chloroform deproteinization with phenol deproteinization was used, since when following the procedure of Marmur 
(1961) it was found difficult with some DNA samples to decrease the protein content below $1 \%$ even after performing chloroform deproteinizations 8 times. Strains sensitive to lysozyme were incubated with $0.5 \mathrm{mg}$. lysozyme $/ \mathrm{ml}$. bacterial suspension in a $\mathrm{NaCl}+\mathrm{EDTA}$ solution at $37^{\circ}$ for $10-60 \mathrm{~min}$. A $25 \%(\mathrm{w} / \mathrm{v})$ solution of sodium dodecyl sulphate was then added to make the final concentration $2 \%$; lysis was then complete at $60^{\circ}$ in $10 \mathrm{~min}$. After the mixture had been cooled to room temperature, sodium perchlorate was added to $\mathrm{M}$ concentration and one volume of a mixture of chloroform + isoamyl alcohol $(24+1, \mathrm{v} / \mathrm{v})$. After $30 \mathrm{~min}$. shaking and $20 \mathrm{~min}$. centrifugation at $5000 \mathrm{rev} . / \mathrm{min}$. the upper layer was removed and precipitated with 1.5 volume ethanol. The resulting fibrous DNA precipitate was dissolved in 10-fold dilution of standard saline citrate buffer $\mathrm{pH} 7(0.15 \mathrm{M}-\mathrm{NaCl}+0.015 \mathrm{M}$-sodium citrate, $\mathrm{pH} 7$; hereafter SSC) and after its solution the saline citrate buffer concentration was adjusted to SSC with $10 \times$ SSC and ribonuclease $(5 \times$ cryst. Reanal, Hungary) added $50 \mu \mathrm{g} . / \mathrm{ml}$. After incubation for $30 \mathrm{~min}$. at $37^{\circ}, \mathrm{NaCl}$ was added to the solution to $\mathrm{M}$ concentration and a further equal volume of re-distilled phenol saturated with $\mathrm{M}-\mathrm{NaCl}+0 \cdot 1 \mathrm{M}$-tris ( $\mathrm{pH}$ 9). After shaking for $20 \mathrm{~min}$. at $4^{\circ}$, the mixture was centrifuged at $75,000 \mathrm{~g}$ for $30 \mathrm{~min}$. and the clear supernatant layer precipitated with one volume of ethanol.

Deproteinization with a mixture of chloroform + isoamyl alcohol $(24+1)$ was done twice and as a rule, after the second deproteinization, no interlayer of protein was formed after centrifugation. The DNA sample was precipitated with one volume of ethanol again. By this procedure, the amount of phenol in the sample decreased below $0.5 \%$; this was detected spectrophotometrically by measuring the ratio $E_{260}: E_{235}$ in a medium of $0.1 \mathrm{M}-\mathrm{NaOH}$ (Boháček, 1966). The ethanol-precipitated DNA was dissolved in a 10 -fold diluted SSC and $1 / 10$ volume of $3 \mathrm{M}$-sodium acetate in $10^{-3} \mathrm{M}$ EDTA added. The DNA was precipitated by adding 0.55 to 0.7 volume of re-distilled 2-propanol with constant stirring. After twice washing in $75 \%(\mathrm{w} / \mathrm{v})$ ethanol in water the DNA was dissolved in phosphate +EDTA (0.01 M-sodium phosphate +0.001 M-EDTA, pH 7) buffer (PE).

For the measurement of the DNA melting curves a spectrophotometer, type Beckman DU, was used. The cell holder compartment was thermostated at both sides by two thermospacers for circulating hot water from a U-10 ultra thermostat. The temperature was measured with a rod thermometer directly in one of the cuvettes. The melting curves were not corrected for thermal expansion of the solution. The solvent used was $10^{-2} \mathrm{M}$-sodium phosphate buffer $(\mathrm{pH} 7)+10^{-3} \mathrm{M}$-EDTA which contained the following substances per liter of solution: $0.608 \mathrm{~g}$. $\mathrm{NaH}_{2} \mathrm{PO}_{4} \cdot 2 \mathrm{H}_{2} \mathrm{O}, 2 \cdot 18 \mathrm{~g}$. $\mathrm{Na}_{2} \mathrm{HPO}_{4} \cdot 12 \mathrm{H}_{2} \mathrm{O}, 0.372 \mathrm{~g}$. disodium salt of EDTA, $1 \mathrm{ml}$. N-NaOH . An example of a melting curve and its evaluation is given in Fig. 1.

The \% GC content was calculated according to the equation $T_{m}=51+0.45$ (GC) derived from the dependence of $T_{m}$ on the GC content determined in DNA by paper chromatography (unpublished results) and according to the results from the method of Frédéricq et al. (1961). The width of the transition interval $(\Delta T)$ was established as the difference between temperatures from 17 to $83 \%$ of the over-all increase in $E_{260}$ and the value $2 \sigma=(\Delta T-3) .2 .5$ was calculated from it. The values $2 \sigma$ and $3 \sigma$ served then to express graphically the heterogeneity of the sample according to De Ley \& van Muylem (1963).

As a second control method for determining the $\% \mathrm{GC}$ content in isolated samples 
of DNA, the method of Frédéricq et al. (1961) was used. This method is based on the fact that the extinction ratio of $260: 280 \mathrm{~m} \mu\left(E_{260}: E_{280}\right)$ measured in a medium of $0 \cdot 1$ $\mathrm{M}$-acetic acid ( $\mathrm{pH} 3$ ) is dependent on the \% GC content in DNA. The samples of DNA were dissolved in a PE medium in a concentration of approximately $2 \mathrm{mg} . / \mathrm{ml}$. Before measurement, $0 \cdot 1 \mathrm{M}$-acetic acid was added to the final concentration of DNA, 20-30 $\mu \mathrm{g} / \mathrm{ml}$. The measurements of o.D. at 260 and $280 \mathrm{~m} \mu$ respectively were made with a type Zeiss VSU-1 spectrophotometer. For pH measurements a pH-meter type PYE-Master was used.

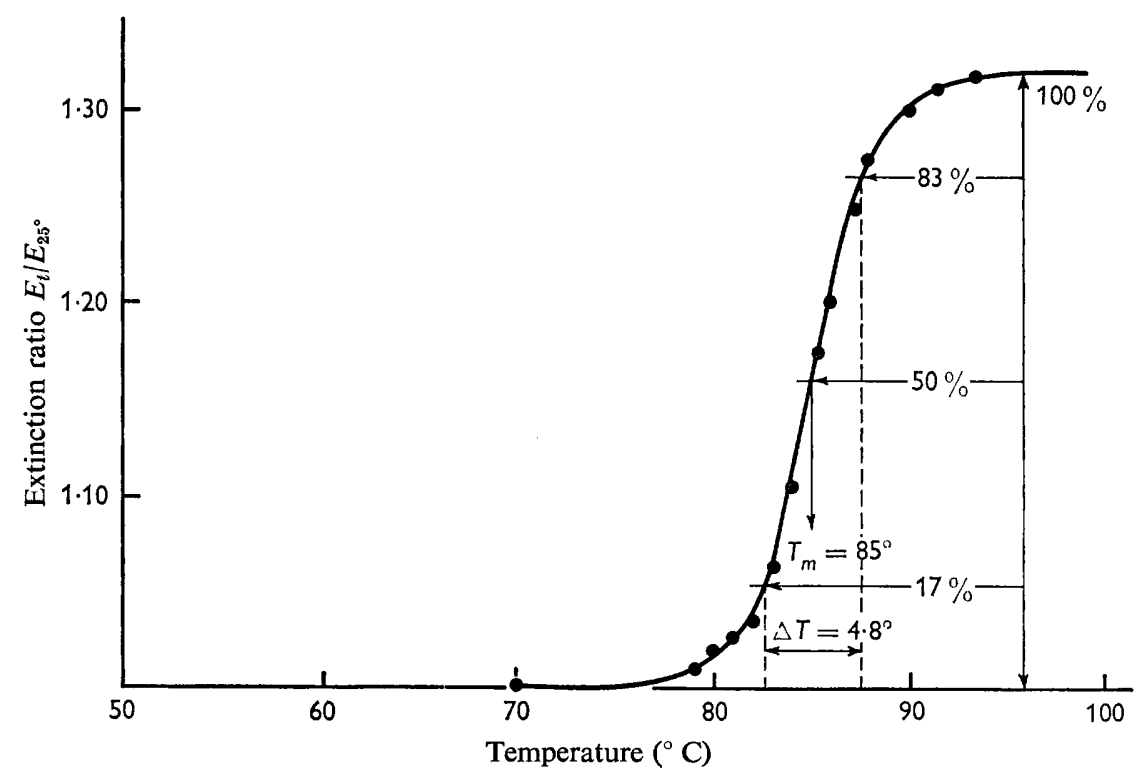

Fig. 1. Example of the evaluation of the melting curve of DNA of Micrococcus luteus, no. 409. Ordinate extinction ratio $E_{260}$ at the given temperature $(t)$ to $E_{260}$ at the basal temperature $25^{\circ}$. The over-all increase in extinction ratio is designated as $100 \%, T_{m}$ corresponds to $50 \%$ of the over-all increase in $E_{280}$. From the course of the melting curve within the temperature range of $17-83 \% E_{260}$, the interval $\Delta T\left(\Delta \frac{2}{3}\right)$ is subtracted, from which $2 \sigma=$ $(\Delta T-3) 2 \cdot 5$ is calculated.

\section{RESULTS AND DISCUSSION}

For determining the $\%$ GC content in the DNA of the micrococci examined, two different methods were used; besides the method of determining the \% GC content from the $T_{m}$ value (Marmur \& Doty, 1962) we also used the method of determining $\%$ GC according to the ratio $E_{260}: E_{280}$ at $\mathrm{pH} 3$ (Frédéricq et al. 1961). The difference between the values obtained by the two methods were within the range of $1-3 \%$ GC (see Table 2). Greater differences between the results given by the two methods would indicate the presence of impurities in the DNA preparations. In our opinion, the method recommended by Frédéricq et al. (1961) is useful for a rapid and orientating determination of $\%$ GC. However, since this method does not furnish data on the heterogeneity of DNA molecules it is advisable to use in parallel the method of $T_{m}$ determination to obtain more detailed information.

The results (Table 2) show that the strains examined can be divided into three groups. The first, most numerous, group (Fig. 2) includes 17 strains (8 Micrococcus luteus, 
$5 \mathrm{M}$. roseus, 3 Micrococcus spp., $1 \mathrm{M}$. litoralis) whose $\%$ GC in DNA was in agreement with their classification as given by Kocur \& Martinec (1962). Our results also confirm the opinion of these authors that aerobic Gram-positive yellow-pigmented cocci which do not attack glucose should be classified as $M$. luteus. The \% GC values found in strains of $M$. luteus and $M$. roseus are in agreement with the data given by Belozersky \& Spirin (1960) and by Silvestri \& Hill (1965). In contrast, Rosypalová et al. (1966) found only $66 \cdot 3 \% \mathrm{GC}$ in the DNA of the type culture of $M$. luteus ATCC 398. Only one strain from our series ( $M$. luteus CCM 169, NCTC2665) was also studied by Silvestri \& Hill (1965). Their result $72 \cdot 8 \%$ GC agrees with the value of $73 \cdot 3 \% \mathrm{GC}$ found by us.

Table 2. DNA base composition of some micrococci

\begin{tabular}{|c|c|c|c|c|c|c|}
\hline Name & CCM no. & $T_{m}\left({ }^{\circ} \mathrm{C}\right)$ & $\%$ GC & $2 \sigma$ & $\begin{array}{c}E_{260 / 280} \\
\mathrm{pH}=3\end{array}$ & $\%$ GC \\
\hline Micrococcus luteus & $\left\{\begin{array}{r}132 \\
840 \\
1674 \\
337 \\
169 \\
410 \\
149 \\
409\end{array}\right.$ & $\begin{array}{l}83 \cdot 0 \\
83 \cdot 0 \\
83 \cdot 2 \\
83 \cdot 6 \\
84 \cdot 0 \\
84 \cdot 2 \\
84 \cdot 6 \\
85 \cdot 0\end{array}$ & $\begin{array}{l}71 \cdot 0 \\
71 \cdot 0 \\
71 \cdot 5 \\
72 \cdot 3 \\
73 \cdot 3 \\
73 \cdot 7 \\
74 \cdot 6 \\
75 \cdot 5\end{array}$ & $\begin{array}{l}2 \cdot 5 \\
2 \cdot 5 \\
0 \\
4 \cdot 5 \\
2 \cdot 0 \\
2 \cdot 5 \\
3 \cdot 0 \\
3 \cdot 30\end{array}$ & $\begin{array}{c}1 \cdot 130 \\
1 \cdot 050 \\
1 \cdot 090 \\
1 \cdot 100 \\
-\overline{100} \\
1 \cdot 070 \\
1 \cdot 080\end{array}$ & $\begin{array}{c}67 \cdot 0 \\
72 \cdot 0 \\
71 \cdot 0 \\
70 \cdot 0 \\
- \\
70 \cdot 0 \\
73 \cdot 0 \\
72 \cdot 0\end{array}$ \\
\hline Micrococcus roseus & $\left\{\begin{array}{r}679 \\
837 \\
385 \\
560 \\
633 \\
168 \\
1405\end{array}\right.$ & $\begin{array}{l}82 \cdot 0 \\
82 \cdot 4 \\
83 \cdot 0 \\
83 \cdot 0 \\
83 \cdot 8 \\
73 \cdot 2 \\
73 \cdot 2\end{array}$ & $\begin{array}{l}69 \cdot 0 \\
69 \cdot 7 \\
71 \cdot 0 \\
71 \cdot 0 \\
72 \cdot 8 \\
49 \cdot 3 \\
49 \cdot 3\end{array}$ & $\begin{array}{l}3.0 \\
3.0 \\
4.5 \\
2.5 \\
0.75 \\
0.5 \\
4.5\end{array}$ & $\begin{array}{l}1 \cdot 120 \\
1 \cdot 100 \\
1 \cdot 120 \\
1 \cdot 100 \\
1 \cdot 100 \\
1 \cdot 400 \\
1 \cdot 330\end{array}$ & $\begin{array}{l}68 \cdot 0 \\
70 \cdot 0 \\
68 \cdot 0 \\
70 \cdot 0 \\
69 \cdot 0 \\
45 \cdot 0 \\
50 \cdot 5\end{array}$ \\
\hline Micrococcus litoralis & 2226 & $80 \cdot 5$ & $65 \cdot 0$ & $4 \cdot 0$ & $1 \cdot 170$ & $63 \cdot 5$ \\
\hline Micrococcus spp. & $\left\{\begin{array}{r}740 \\
836 \\
2087 \\
825\end{array}\right.$ & $\begin{array}{l}77 \cdot 4 \\
81 \cdot 7 \\
81 \cdot 7 \\
82 \cdot 2\end{array}$ & $\begin{array}{l}58 \cdot 6 \\
68 \cdot 3 \\
68 \cdot 3 \\
69 \cdot 5\end{array}$ & $\begin{array}{l}8 \cdot 5 \\
1 \cdot 5 \\
0 \\
0\end{array}$ & $\begin{array}{c}1 \cdot 250 \\
1 \cdot 165 \\
1 \cdot 165 \\
-\end{array}$ & $\begin{array}{c}53 \cdot 5 \\
64 \cdot 0 \\
64 \cdot 0 \\
-\end{array}$ \\
\hline Micrococcus cerolyticus & 901 & $67 \cdot 0$ & 35.6 & $5 \cdot 0$ & 14.90 & $39 \cdot 0$ \\
\hline Micrococcus denitrificans & $\left\{\begin{array}{r}982 \\
1396\end{array}\right.$ & $\begin{array}{l}79 \cdot 8 \\
80 \cdot 6\end{array}$ & $\begin{array}{l}64 \cdot 0 \\
66 \cdot 3\end{array}$ & $\begin{array}{l}4 \cdot 5 \\
1.5\end{array}$ & $\begin{array}{l}1 \cdot 160 \\
1 \cdot 130\end{array}$ & $\begin{array}{l}64 \cdot 0 \\
67 \cdot 0\end{array}$ \\
\hline Micrococcus halodenitrificans & 286 & $80 \cdot 2$ & $65 \cdot 0$ & 0.5 & $1 \cdot 140$ & $66 \cdot 0$ \\
\hline Micrococcus radiodurans & $\left\{\begin{array}{l}1700 \\
1701\end{array}\right.$ & $\begin{array}{l}82 \cdot 0 \\
80 \cdot 4\end{array}$ & $\begin{array}{l}69 \cdot 0 \\
65 \cdot 3\end{array}$ & $\begin{array}{l}3 \cdot 25 \\
4 \cdot 3\end{array}$ & $\begin{array}{l}1 \cdot 140 \\
1 \cdot 145\end{array}$ & $\begin{array}{l}66.0 \\
65 \cdot 5\end{array}$ \\
\hline Micrococcus cryophilus & 900 & $69 \cdot 9$ & $41 \cdot 3$ & $3 \cdot 5$ & $1 \cdot 410$ & $44 \cdot 5$ \\
\hline Micrococcus aquivivus & 316 & $74 \cdot 0$ & $51 \cdot 2$ & $3 \cdot 5$ & $1 \cdot 375$ & $47 \cdot 5$ \\
\hline Micrococcus eucinetus & $\left\{\begin{array}{l}2388 \\
2389\end{array}\right.$ & $\begin{array}{l}72 \cdot 6 \\
73 \cdot 6\end{array}$ & $\begin{array}{l}48 \cdot 0 \\
50 \cdot 3\end{array}$ & $\begin{array}{l}3 \cdot 25 \\
4 \cdot 0\end{array}$ & $\begin{array}{l}1.370 \\
1 \cdot 350\end{array}$ & $\begin{array}{l}47 \cdot 5 \\
49 \cdot 0\end{array}$ \\
\hline
\end{tabular}

The second heterogeneous group of strains (Fig. 2) consisted of those which would appear to need reclassification since they substantially differed in their $\%$ GC content from the value for the genus Micrococcus. This group contains Micrococcus sp. 740, $M$. cerolyticus 901 , and $M$. cryophilus 900 . With the exception of strain 740 , these strains also differed in their cultural and biochemical properties from the species within the genus Micrococcus. $M$. cerolyticus had already been found by us to be identical on biochemical properties with Staphylococcus epidermidis. The finding of a low \% GC 
value (35.6-39.0) is compatible with the suggestion that this is a strain of $S$. epidermidis. As Marmur et al. (1963) reported, we also found a low \% GC (41.3\%) in the DNA of $M$. cryophilus. These results support the opinion of Mazanec, Kocur \& Martinec (1966) that $M$. cryophilus should be discarded from the genus Micrococcus. The $\%$ GC values of $M$. denitrificans, $M$. halodenitrificans and $M$. radiodurans are lower than in most strains within the genus Micrococcus; these results agree with those of Marmur et al. (1963) and Moseley \& Schein (1964). The above species were proposed by Baird-Parker (1965) for transfer to Gram-negative genera.

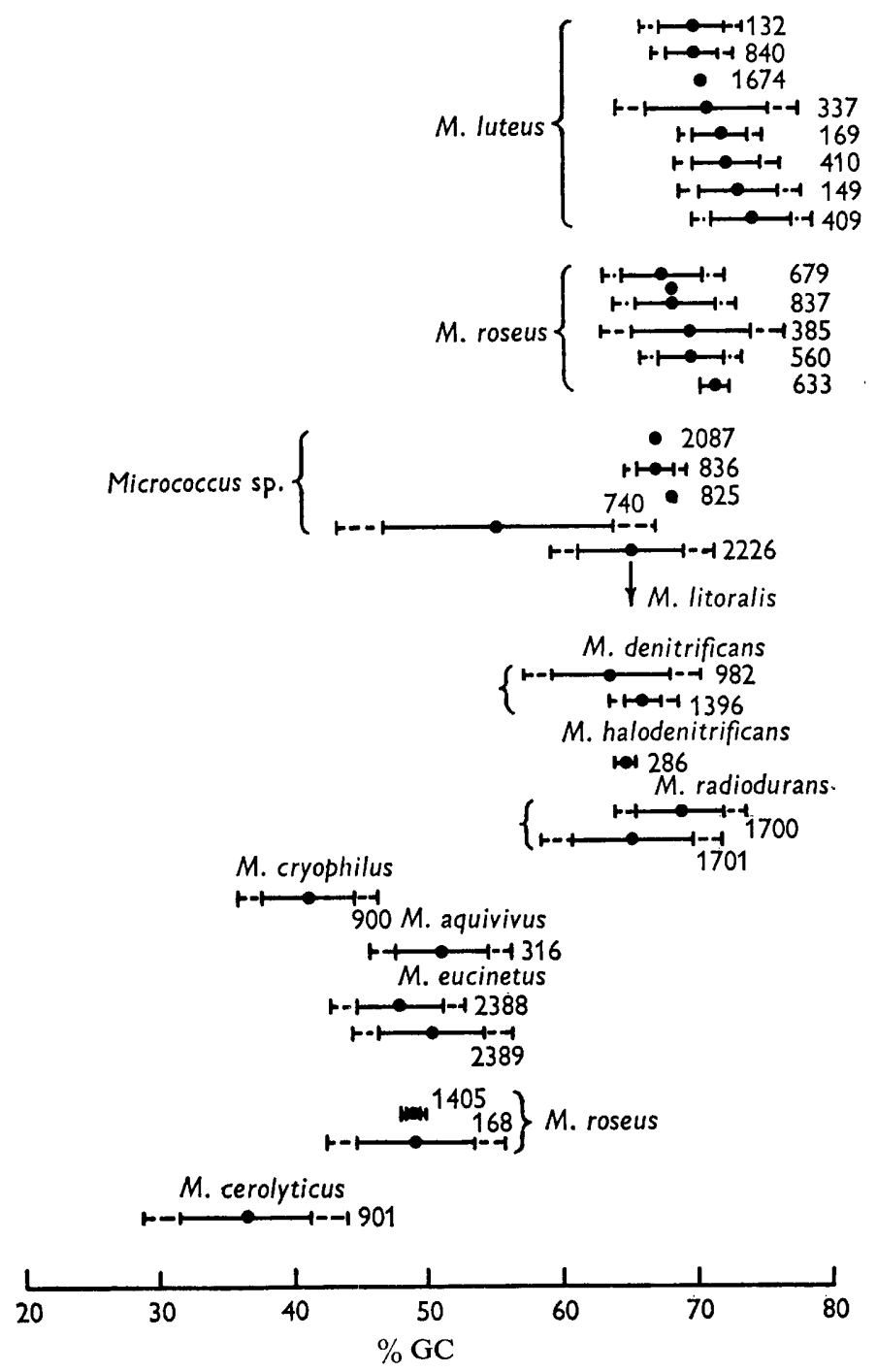

Fig. 2. Survey of the mean base composition and the exponential distribution of DNA molecules of various micrococci. The strains are designated by numbers (see Table 1). The horizontal lines are the projections of the Gaussian curves on the plane of the paper, their maxima being average \% GC. The full horizontal lines represent $\% \mathrm{GC} \pm 2 \sigma$, and encompass about $95 \%$ of the DNA molecules. The total length of each full line + dashed line represents $\% \mathrm{GC} \pm 3 \sigma$ and encompasses about $99.7 \%$ of the DNA molecules. 
The third group, comprising five strains, is of special interest from the standpoint of the $\%$ GC content in DNAs and its variability. The group includes two strains of Micrococcus eucinetus, two of M. roseus (168 and 1405), and one of M. aquivivus. These strains are interesting not only because they occupy an intermediate position in their \% GC content (48-51\%) between the values for the genera Staphylococcus and Micrococcus, but also because they form a tight cluster around a mean value of $50 \%$ GC. Also interesting is the fact that three of these strains are marine strains, and in the case of the other two strains (M. roseus CCM 168 and 1405) the possibility of an original marine habitat cannot be excluded. Our results support to some extent Belser's (1964) conception of an evolutionary affinity among marine bacteria. Of course, in contrast to Belser's (1964) finding of a very tight cluster (around $41 \%$ GC in DNA) among Gramnegative marine bacteria, our Gram-positive marine micrococci form a very tight cluster around a mean of $50 \%$ GC. On the other hand, we found (unpublished data) that some marine micrococci. e.g. M. maripuniceus ATCC 14399 had $73 \%$ GC similar to that of species of Micrococcus, but M. euryhalis ATCC 14389 had 33\% GC in DNA, similar to the species of the genus Staphylococcus. Consequently, before general conclusions about the phylogeny of marine bacteria can be drawn from the above results, many more strains of these bacteria must be investigated. Since the strains of marine cocci studied by us show marked differences in their \% GC content from species of Micrococcus it is recommended that these cocci should be discarded from the genus Micrococcus and a more suitable taxonomic position found for them. Komagata (personal communication) recommends that $M$. eucinetus should be placed in the genus Planococcus Migula in view of its motility and \% GC content in DNA. In our opinion, for the same reason the strains designated as M. aquivivus ссм 316 and M. roseus CCM 168 and 1405 should also be placed in the genus Planococcus.

The results obtained in the present work support the correctness of the methodological principles suggested by Silvestri \& Hill (1965), and also confirm the correctness of Evans's (1965) proposal to recognize only two species within the genus Micrococcus: $M$. luteus and $M$. roseus.

\section{REFERENCES}

Auletta, A. E. \& Kennedy, E. R. (1966). Deoxyribonucleic acid base composition of some members of the Micrococcaceae. J. Bact. 92, 28.

Baird-Parker, A. C. (1965). The classification of staphylococci and micrococci from world-wide sources. J. gen. Microbiol. 38, 363.

BELSER, W. L. (1964). DNA base composition as an index to evolutionary affinities in marine bacteria. Evolution, 18, 177.

Belozersky, A. N. \& Spirin, A. S. (1960). In The Nucleic Acids. Ed. by E. Chargaff and J. N. Davidson. Vol. 3. New York: Academic Press.

BOHÁČEK, J. (1966). Spectrophotometric method for the estimation of phenol in preparations of nucleic acids. Abst. 4th Meet. Czech. Soc. Biochem. p. 12.

BohÁČEK, J., KoCUr, M. \& MARTINEC, T. (1965). Deoxyribonucleic acid base composition and taxonomy of the genus Micrococcus. Publs. Fac. Sci. Univ. J. E. Purkynĕ, Brno K 35, 318.

De LeY, J. \& VAN MUYLEM, J. (1963). Some application of deoxyribonucleic acid base composition in bacterial taxonomy. Antonie van Leeuwenhoek 29, 344.

Evans, J. B. (1965). Current views and problems relating to the taxonomy of the Micrococcaceae. Int. Bull. Bact. Nomencl. Taxon. 15, 111.

FrédéricQ, E., OTh, A. \& Fontaine, F. (1961). The ultraviolet spectrum of DNA and their constituents. J. mol. Biol. 3, 11.

Kocur, M. \& Martinec, T. (1962). A taxonomic study of the genus Micrococcus. Folia Fac. Sci. Natur. Univ. Purkynianae Brunensis 3, 3. (In Czech.) 
MARMUR, J. (1961). A procedure for the isolation of deoxyribonucleic acid from microorganisms. J. mol. Biol. 3, 208.

MARMuR, J. \& Doty, P. (1962). Determination of the base composition of deoxyribonucleic acid from its thermal denaturation temperature. J. mol. Biol. 5, 109.

Marmur, J., Falkow, S. \& Mandel, M. (1963). New approaches to bacterial taxonomy. A. Rev. Microbiol. 17, 329.

Mazanec, K., Kocur, M. \& Martinec, T. (1966). Electron microscopy of ultrathin sections of Micrococcus cryophilus. Canad. J. Microbiol. 12, 465.

Moseley, B. E. B. \& ScheIN, A. H. (1964). Radiation resistance and deoxyribonucleic acid base composition of Micrococcus radiodurans. Nature, Lond. 203, 1298.

RosYPALOVÁ, A., BOHÁČEK, J., RosYPAL, S. (1966). Deoxyribonucleic acid base composition of some micrococci and sarcinae. Antonie van Leeuwenhoek 32, 192.

Silvestri, L. G. \& HiLl, L. R. (1965). Agreement between DNA base composition and taxometric classification of Gram-positive cocci. J. Bact. 90, 136. 